\title{
A Patient Using Varenicline During Smoking Cessation and Diagnosed with Type 1 Diabetes: A Case Report
}

\author{
Sigara Bırakma Sürecinde Vareniklin Kullanan, Tip 1 Diyabet Tanısı Alan \\ Hasta; Olgu Sunumu
}

Selin Adatepe Yapıcı ${ }^{1}$, Ayşe Elif Özmen ${ }^{1}$, Muhammet Hasar ${ }^{l}$, Z. Yelda Özer ${ }^{*}$, Çiğgdem Gereklioğlu ${ }^{l}$, Sevgi Özcan ${ }^{l}$

\begin{abstract}
Varenicline is one of the treatment options in smoking cessation treatments. It is known that varenicline can predispose to diabetes or trigger diabetes and negatively affect glucose control. This effect has been reported as "uncommon side effects, may affect up to 1 person in every 100 people". In the present case; A 21 -year-old male, nicotine-addicted patient is presented with the diagnosis of Type 1 Diabetes during the use of varenicline during smoking cessation. Clinicians providing smoking cessation counseling should be careful about the side effects of varenicline.
\end{abstract}

Key words: Varenicline, diabetes mellitus type 1, smoking cessation counseling

\section{ÖZET}

Sigara bırakma tedavilerinde vareniklin tedavi seçeneklerinden biridir. Vareniklinin diyabete yatkınlık oluşturabileceği veya diyabeti tetikleyebileceği ve glikoz kontrolünü olumsuz etkileyebileceği bilinmektedir. Bu etki, "yaygın olmayan yan etkiler, her 100 kişide en fazla 1 kişiyi etkileyebilecek" şeklinde bildirilmiştir. Bu olgu sunumunda 21 yaşında nikotin bağımlısı bir erkek hastanın sigara bıraktırma sürecinde vareniklin kullanımı sırasında Tip 1 diyabet tanısı alması bildirilmiştir. Sigara bıraktırma danışmanlığı veren klinisyenlerin, vareniklinin yan etkileri konusunda dikkatli olmaları gerekmektedir.

Anahtar kelimeler: Vareniklin, Diabetes mellitus Tip 1, sigara bıraktırma danışmanlığ1

Received / Geliş tarihi: 24.08.2020, Accepted / Kabul tarihi: 09.12.2020

${ }^{1}$ Çukurova Üniversitesi Tıp Fakültesi Aile Hekimliği Anabilim Dalı, Sarıçam, Adana.

*Address for Correspondence / Yazışma Adresi: Z. Yelda Özer, Çukurova Üniversitesi Tıp Fakültesi, Aile Hekimliği Anabilim Dalı, Sarıçam, AdanaTürkiye. E-mail: z.yeldaozer@gmail.com

Adatepe Yapıcı S, Özmen AE, Hasar M, Özer ZY, Gereklioğlu Ç, Özcan S. A Patient Using Varenicline During Smoking Cessation and Diagnosed with Type 1 Diabetes: A Case Report. TJFMPC, 2021;15(1): 202-204.

DOI: $10.21763 /$ tjfmpc. 779217 


\section{Gİiş̧}

Sigara bırakma tedavisinde davranışçı ve bilişsel yöntemlerin yanı sıra farmakolojik ajanlar da kullanılmaktadır. Farmakolojik tedavide günümüzde birçok seçenek bulunmakla birlikte bant /sakız gibi nikotin yerine koyma tedavileri ve son yıllarda kullanıma giren bupropion ve vareniklin ülkemizde en sık kullanılan tedavi yöntemleridir. Vareniklin, santal sinir sistemindeki nikotinik reseptörlerden $\alpha 4 \beta 2$ 'yi uyararak nikotinik agonistik etki ile dopamin salınımını sağlar. ${ }^{1}$ Vareniklin, sigara biraktırma tedavisinde temel farmakolojik yöntemlerden biridir ve genellikle on iki hafta kullanılması önerilir. Bilindiği gibi, rastgele plazma glikoz düzeyinin $200 \mathrm{mg} / \mathrm{dl}$ 'nin üzerinde veya eşit ve beraberinde diyabet semptomlarının olması aşikar diyabeti tanımlamaktadır. ${ }^{2}$ Vareniklinin glikoz metabolizması üzerinde diyabet, hipoglisemi/hiperglisemi oluşturma gibi yan etkilerinin olduğu bilinmektedir. ${ }^{3}$

$\mathrm{Bu}$ olgu sunumuyla klinisyenlerin dikkatini vareniklinin glikoz kontrolünü olumsuz etkileyebileceği konusuna çekmeyi hedefledik.

\section{OLGU}

Üniversitemizin Eğitim Aile Sağlığı Merkezi’ne (EASM) kayıt olmak için başvuran 21 yaşındaki erkek hastadan öykü alınması esnasında sigara içtiğinin (5 yıldır günde 1 paket) saptanması üzerine sigara bırakma danışmanlığı süreci başlatıldı. Fagerström testine göre yüksek düzeyde bağımlılık (bağımlılık skoru:7) saptanan hastaya farmakolojik tedavi önerildi. Üniversitemizde Sigara Bırakma Polikliniği bulunmadığı için "Alo 171 Sigara Bırakma Danışma Hattı” yardımıyla bu merkezlerin herhangi birinden randevu alabileceği ve ilaçlarını ücretsiz sağlayabileceği bilgisi verildi. $\mathrm{Bu}$ süreçte hasta, tarafımızdan danışmanlık hizmeti verebilmek ve kontrol amaçlı telefon ile arandı ama yanıt alınamadi. İlk başvurudan iki ay sonra polikliniğimize yeni gelişen diyabet hastalığ1 nedeniyle şeker ölçüm çubuklarını yazdırmak için başvuran hastanın dış merkezde sigara bırakma polikliniğine başvurduğu, o gün yapılan tetkiklerinde kan şekerinin $202 \mathrm{mg} / \mathrm{dl}$ olarak ölçüldüğü (hastanın 2 ay önceki açlık plazma glikoz düzeyi $78 \mathrm{mg} / \mathrm{dl}$ idi); hastaya vareniklin başlandığı, yaklaşık üç hafta tedaviye devam ettiği, ağız kuruluğu şikayeti artınca aynı dış merkezin dahiliye bölümüne başvurduğu; HbA1c değerinin \%14, kan şekerinin $620 \mathrm{mg} / \mathrm{dl}$ gelmesi üzerine diyabet tanısıyla üç gün dahiliye servisinde yatırıldığı, insülin reçetesiyle taburcu edildiği, hastalığı ile ilgili herhangi bir eğitim almadığı tespit edildi. Soy geçmişinde amcasında Tip 1 diyabet olduğu öğrenilen hastanın tanısını kabullenmede zorluk yaşadığı, diyabetin ilaç (vareniklin) kullanımına bağlı ve geçici olabileceğini düşündüğü saptand1. Vücut ağırlığı $48 \mathrm{~kg}$ olan hastanın (Boy:164 cm, VKİ: $17,8 \mathrm{~kg} / \mathrm{m}^{2}$ ) poliklinikte kan şekeri $62 \mathrm{mg} / \mathrm{dl}$ ölçüldü. Evde de bir kez gece titreme, terleme, çarpıntı gibi hipoglisemi semptomlarının gözlendiği ve bu esnada glikoz stripti ile yapılan ölçümde kan şekerinin $54 \mathrm{mg} / \mathrm{dl}$ ölçüldüğü öğrenildi. Tıbbi ve sosyal endikasyon nedeniyle yatış düşünülen hasta, endokrin ile konsülte edildi ancak mevcut koşullar nedeniyle hastanın ayaktan tetkiklerinin yapılması ve tedavisi planland. Hastanın Endokrin polikliniğinde yapılan tetkiklerinde; anti-GAD $(+)$, C peptid düzeyi $0,439 \mu \mathrm{g} / \mathrm{L}$ (referans aralık: 0,9$7,1 \mu \mathrm{g} / \mathrm{L})$ bulundu. Hipoglisemi atakları olması nedeniyle insülin dozları düzenlenen hastaya ve yurtta birlikte kaldığı arkadaşına ana/ara öğün, glisemik indeks, hipoglisemi, insülin kullanımı ve şeker ölçümü ile ilgili eğitim verildi. Diyabetin akut ve kronik komplikasyonları, yapılması gereken rutin muayene ve tetkikler (ayak muayenesi, göz muayenesi, 3 ayda bir HbA1c takibi vs) anlatıldı. Hastanın diyetisyen ve psikolog ile görüşmesi için randevu alındı. İnsülin tedavisine devam eden hasta, sigarayı bırakmadığını ifade ederek, pandemi ve sınavı olduğu gerekçesiyle de kontrollerine gelmedi. Olgu sunumu için hastadan sözel onam alındı.

\section{TARTIŞMA}

Başta kronik obstruktif akciğer hastalıkları olmak üzere; kanser, kalp hastalıkları, diyabet ve psikiyatrik hastalıklarda sigara bırakma tedavi seçeneği olarak vareniklin çokça tercih edilen bir ilaçtır. Literatürde de vareniklinin psikiyatrik ve kardiyovasküler yan etkileri üzerinde yapılmış araştırmalar yoğunluktadır., ${ }^{4,5}$ Hipoglisemi / hiperglisemi gibi yan etkileri yaygın olmayan yan etkilerden olsa da vareniklin bizim olgumuzda yeni başlangıçlı diyabetin kliniğini olumsuz yönde etkilemiş olabilir. Literatür taramasında bu konuyla ilgili meta-analiz ya da sistematik derlemeye rastlanmamıştır. Yapılan araştırmalarda da vareniklinin mitokondriyal disfonksiyon yoluyla pankreastaki normal beta hücrelerini bozma potansiyeline sahip olduğu tespit edilmiştir. ${ }^{6}$

Türk Toraks Derneği "Sağlık kuruluşlarına başvuran bireyler hangi sebeple gelmiş olursa olsunlar sigara içme durumları mutlaka sorulmalıdır" önerisinde bulunmaktadır. ${ }^{7} \mathrm{Bu}$ olguda da, EASM'ye kayıt için başvuran hastanın kapsamlı değerlendirilmesi sırasında yüksek düzeyde nikotin bağımlılığı tespit edilip farmakolojik tedavi önerilmiştir. Ancak farmakolojik tedavi yeni başlayan Tip 1 diyabet kliniğinin olumsuz etkilenmesine neden olmuştur.

Hasta diyabet tanısını diş merkezde almıştır. EASM'ye ilaçlarını yazdırmak için başvurduğunda hastalığı ile ilgili yeterli eğitim 
almadığ1 gözlenmiştir. İlk tanısı sırasında yurtta tek başına kalıyor olması gibi özel durumlar da göz önünde bulundurulmamıştır. Yeni tanı aldığı dönemde kontrole gelmediği ve iletişimi sürdürmediği için hastaya diyabet ile ilgili eğitim verilmesi, ögünlerinin düzenlenmesi ve psikolojik destek sağlanamamıştır. Oysa ki, aile hekimliğinin kişi merkezli bakım çekirdek yeterliğine göre; hasta ve ortama dayal1, hastayla ortak karar verme esastır ve hasta-hekim ilişkisi önem arz eder. Tüm bu etkenler hastanın diyabet kontrolünün başarısız olmasının nedeni olarak düşünülebilir.

\section{SONUÇ}

Araştırmalarımız sonucunda literatürde bu tarz bir olgu raporuna rastlanmamıştır. Bu olgu sunumu ile vareniklinin reçetelenmesi sırasında psikiyatrik, kardiyovasküler hastalıklar kadar hastanın plazma glikoz düzeyinin de göz önünde bulundurulmasının gerekliliği vurgulanmak istenmiştir. Klinisyenler vareniklin başlarken hastalarının plazma glikoz düzeyine de dikkat etmelidirler.Sigara ile diyabete bağlı komplikasyonların ortaya çıkma riski arasında çok ciddi bir ilişki olduğu da düşünülerek bu hasta grubunda sigara birakma tedavileri öncelikli olarak planlanmalı ve tedavi seçenekleri ayrıntılı değerlendirilerek uygulanmalıdır.

\section{KAYNAKLAR}

1. Türk Toraks Derneği, Tütün Kontrolü Çalışma Grubu, Sigara Bırakma Tanı ve Tedavi Çalışma Grubu, 2014, Ankara. syf. 35-41.

2. Türkiye Endokrinoloji ve Metabolizma Derneği, Diabetes Mellitus ve Komplikasyonlarının Tanı, Tedavi ve İzlem Klavuzu, 2019, Ankara. syf. 15-16.

3. Champix, Kullanma Talimat, Pfizer PFE İlaçlar1, 2018, İstanbul. Web: https://pdf.ilacprospektusu.com/2064-champix0-5-ve-1-mg-film-kapli-tablet-kt.pdf

4. Tonstad et al.,Psychiatric Adverse Events in Randomized, Double-Blind, PlaceboControlled Clinical Trials of Varenicline, Drug Safety, 2010;33:289-301.

5. Sterling et al., Varenicline and adverse cardiovascular events: a systematic review and meta-analysis of randomized controlled trials, Journal of the American Heart Association, 2016;22:5(2):e00284.

6. Woynillowicz AK et al., The effect of smoking cessation pharmacotherapies on pancreatic beta cell function, Toxicology and Applied Pharmacology 2012;265:122-27.

7. Türk Toraks Derneği, Eğitim Kitapları Serisi, Tütün Kontrolü ve Sigara Bırakma Tedavisi, 2013, Ankara. syf.6. 